\title{
Screening for latent acute intermittent porphyria: the value of measuring both leucocyte $\delta$-aminolaevulinic acid synthase and erythrocyte uroporphyrinogen-1- synthase activities
}

\author{
K E L MCCOLL, M R MOORE, G G THOMPSON, AND A GOLDBERG \\ From the University Department of Medicine, Gardiner Institute, Western Infirmary, Glasgow G11 6NT.
}

SUMMARY Acute intermittent porphyria (AIP) is an autosomal dominantly inherited disorder of haem biosynthesis characterised by reduced activity of the enzyme uroporphyrinogen-1-(URO) synthase and compensatory increased activity of the rate controlling enzyme $\delta$-aminolaevulinic acid (ALA) synthase. Subjects with the disorder should be identified as they are at risk of developing severe porphyric attacks if exposed to a variety of drugs or chemicals. We have assessed the value of measuring the activities of ALA synthase and URO synthase in peripheral blood cells as a means of identifying latent cases in affected families.

In AIP subjects, ALA synthase activity was increased and URO synthase decreased compared to controls, though there was considerable overlap between the two groups when either enzyme was examined alone. When both enzymes were examined together, all but one of the 19 AIP patients had both increased ALA synthase activity ( $>250 \mathrm{nmol}$ ALA $/ \mathrm{g}$ protein $/ \mathrm{h})$ and reduced URO synthase activity $(<25 \cdot 1 \mathrm{nmol} \mathrm{URO} / 1 \mathrm{RBC} / \mathrm{h})$, whereas none of the 62 controls showed this enzyme pattern. Examination of 35 asymptomatic first degree blood relatives of AIP patients showed that $17(49 \%)$ had the porphyric enzyme pattern with no sex bias. The combined study of these two enzymes permits accurate detection of latent cases of AIP and confirms its autosomal dominant inheritance.

Acute intermittent porphyria (AIP) is the result of an inborn error in the pathway of haem biosynthesis which is inherited in an autosomal dominant fashion. ${ }^{1}$ Eight enzymes are involved in the biosynthesis of haem and the rate of the process is controlled by the initial enzyme $\delta$-aminolaevulinic acid (ALA) synthase which is under negative feedback control by haem. The primary defect in AIP is a partial deficiency of the enzyme uroporphyrinogen-1-(URO) synthase. ${ }^{2} 3$ As a result of this partial block in the pathway there is a compensatory increased activity of ALA synthase and a varying degree of overproduction of the porphyrin precursors ALA and porphobilinogen (PBG), which are formed proximal to the block (fig 1). The majority of patients with AIP enjoy good health but on exposure to a variety of factors, including certain drugs and hormones, alcohol, and fasting, are liable to develop severe and sometimes fatal Received for publication 24 September 1981 attacks of neuropsychiatric disturbance associated with markedly increased urinary excretion of ALA and PBG. ${ }^{4}$ The identification of subjects with the genetic trait is important in order that they may be advised to avoid exposure to the known precipitating factors and to ensure early diagnosis and appropriate treatment should an attack occur.

There have been a number of studies assessing methods of detecting latent cases in affected families. Urine analysis is of limited value as increased excretion of ALA or PBG is present in only one in every three latent cases. ${ }^{5}$ Measurement of the activity of URO synthase in peripheral erythrocytes is more sensitive but there is a considerable overlap between normal and porphyric subjects. ${ }^{6-9}$ The interpretation of erythrocyte URO synthase activity in association with the enzyme activities in both parents is helpful in some cases and this combined with urine analysis may permit the classification of up to $90 \%$ of relatives. ${ }^{10-12}$ 


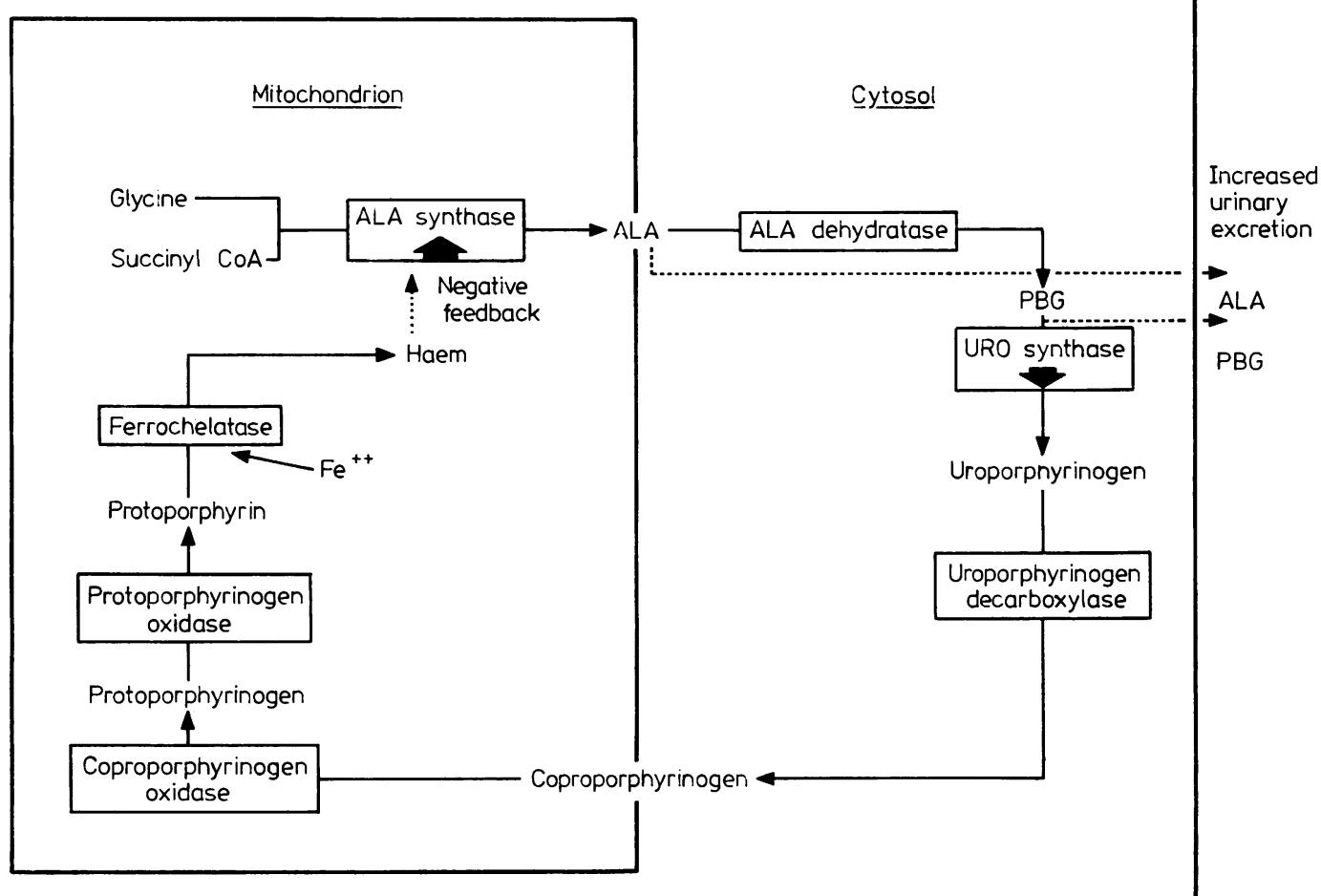

FIG 1 Diagrammatic representation of the pathway of haem biosynthesis. In AIP there is reduced activity of URO synthase and consequently increased activity of $A L A$ synthase and overproduction of the porphyrin precursors $A L A$ and $P B G$.

We have assessed the value of measuring both the activity of ALA synthase in peripheral leucocytes and the activity of URO synthase in peripheral erythrocytes when screening relatives of patients with AIP.

\section{Subjects}

The activities of leucocyte ALA synthase and erythrocyte URO synthase and the 24-hour urinary excretion of ALA and PBG were studied in 19 patients with AIP, 35 blood relatives, and 62 healthy subjects.

\section{PATIENTS WITH AIP}

The AIP patients, who included seven males and 12 females (mean age 30 years, range 8 to 45 years), had all experienced one or more symptomatic attacks with associated increased urinary excretion of ALA and PBG. Nine of these patients were in clinical attack and ten in clinical remission when studied.
RELATIVES OF AIP PATIENTS

Thirty-five first degree blood relatives of 11 of the above mentioned patients were examined. These consisted of fathers (4), mothers (5), brothers (9), sisters (11), sons (2), and daughters (4) of the porphyric patients. Fifteen were males and 20 females (mean age 35 years, range 4 to 65 years). The mean number of relatives studied per index patient was three (range 1 to 8). None of the relatives studied had experienced any symptoms of porphyria.

\section{CONTROLS}

The 62 healthy subjects consisted of 28 females and 34 males with a mean age of 34 years (range 9 to 82 years).

\section{Methods}

For the enzyme assays, $30 \mathrm{ml}$ whole blood was required. 


\section{PREPARATION OF LEUCOCYTES}

Immediately after withdrawal of blood into a heparinised tube and chilling on ice, the blood was centrifuged at $2500 \mathrm{~g}$ for 30 minutes, the plasma removed, and the white cell layer separated from the red cells with a glass rod. The white cells were washed and agitated in ice cold isotonic saline solution until free of any contaminating red cells. The washed white cells were homogenised in 2 vol of the cold isotonic saline (Polytron). An aliquot was taken for protein estimation. ${ }^{13}$

\section{PREPARATION OF ERYTHROCYTES}

The red cells separated by the previous procedure were washed four times and an aliquot taken for packed cell volume measurement after suspension in an equal volume of phosphate buffer $(\mathrm{pH} \mathrm{7.65}$, $83 \mathrm{mmol} / \mathrm{l})$. This suspension was then sonicated (MSE) and used for the assay.

LEUCOCYTE ALA SYNTHASE (EC 2.3.1.37)

This was measured by the method described by Moore et al. ${ }^{14}$ In this, $200 \mu l$ of the white cell homogenate were incubated with $200 \mu$ l of reaction mixture containing $2\left({ }^{14} \mathrm{C}\right)$ glycine as substrate $(250$ $\mu \mathrm{Ci})$ and a total glycine concentration of 375 $\mathrm{mmol} / \mathrm{l}$. This was incubated for 1 hour at $37^{\circ} \mathrm{C}$ in a shaking water bath. The reaction was stopped by addition of $100 \mu \mathrm{l}$ of a solution of $51 \mu \mathrm{mol} / 1 \delta$ aminolaevulinic acid in $1.5 \mathrm{~mol} / 1$ trichloroacetic acid. The precipitate was removed by centrifugation and $20 \mu \mathrm{l}$ of the clear supernatant solution spotted on to strips of Whatman $3 \mathrm{MM}$ paper for electrophoresis. $\delta$-aminolaevulinic acid and glycine were separated by running the electrophoretograms for 1 hour at $2000 \mathrm{~V}$ at $4^{\circ} \mathrm{C}$ in potassium phthalate buffer $(0.05 \mathrm{~mol} / \mathrm{l}$ at $\mathrm{pH} 4)$. After electrophoresis the spots were identified with a ninhydrin solution, cut out, and oxidised in a sample oxidiser (Packard) before beta counting in a scintillation counter (Packard tricarb). The results were expressed as $\mathrm{nmol}$ ALA/g protein/h.

The day to day variation in leucocyte ALA synthase activity has been studied in our laboratory by performing the assay every second day for 28 days in six normal male subjects. The mean coefficient of variation was $15 \%$ (range 8 to $27 \%$ ). ${ }^{15}$

ERYTHROCYTE UROPORPHYRINOGEN-1 SYNTHASE (EC 4.3.1.8) (SYNONYM: PORPHOBILINOGEN DEAMINASE)

This was assayed by a modification of the method of Frydman and Feinstein. ${ }^{16}$ In this, $200 \mu$ red cell haemolysate were incubated with porphobilinogen $(0.82 \mathrm{mmol} / \mathrm{l})$ and reduced glutathione $(3.25 \mathrm{mmol} / \mathrm{l})$ in $83 \mathrm{mmol} / \mathrm{l}$ phosphate buffer, $\mathrm{pH} \mathrm{7.65}$. The reaction was stopped with $10 \mathrm{ml} 2: 1(\mathrm{v} / \mathrm{v})$ ethylacetate: acetic acid. Uroporphyrin in the sample was analysed fluorimetrically against sealed standards and the results expressed as nmol uroporphyrin/l $\mathrm{RBC} / \mathrm{h}$.

Urinary ALA and PBG were measured by the method of Mauzerall and Granick. ${ }^{17}$

\section{Results}

NORMAL CONTROLS

The mean activity of leucocyte ALA synthase in the healthy subjects was $173 \mathrm{nmol}$ ALA/g protein/h (SD \pm 72 , range 40 to 372 ), and the mean activity of erythrocyte URO synthase was $33 \mathrm{nmol}$ URO/1 $\mathrm{RBC} / \mathrm{h}(\mathrm{SD} \pm 7 \cdot 9$, range 16 to 51$)$. The enzyme activities were unaffected by either the age or sex of the subjects.

\section{PATIENTS WITH AIP}

The activity of leucocyte ALA synthase in the AIP patients was markedly increased (mean $908 \mathrm{nmol}$ ALA/g protein/h, range 273 to 3011 ), and the activity of erythrocyte URO synthase was decreased (mean $17 \mathrm{nmol} \mathrm{URO} / \mathrm{l} \mathrm{RBC} / \mathrm{h}$, range 8 to 29) compared with the normal subjects (figs 2,3 ). There was no significant difference between the male and female porphyria patients with respect to either enzyme. No

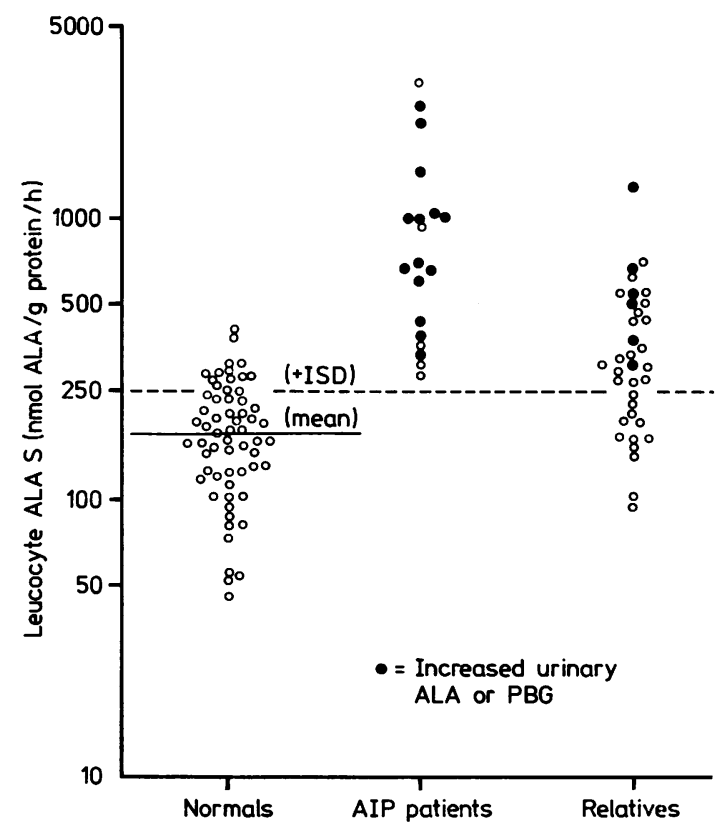

FIG 2 Activity of leucocyte ALA synthase in patients with AIP and in first degree blood relatives in comparison with normal subjects. 


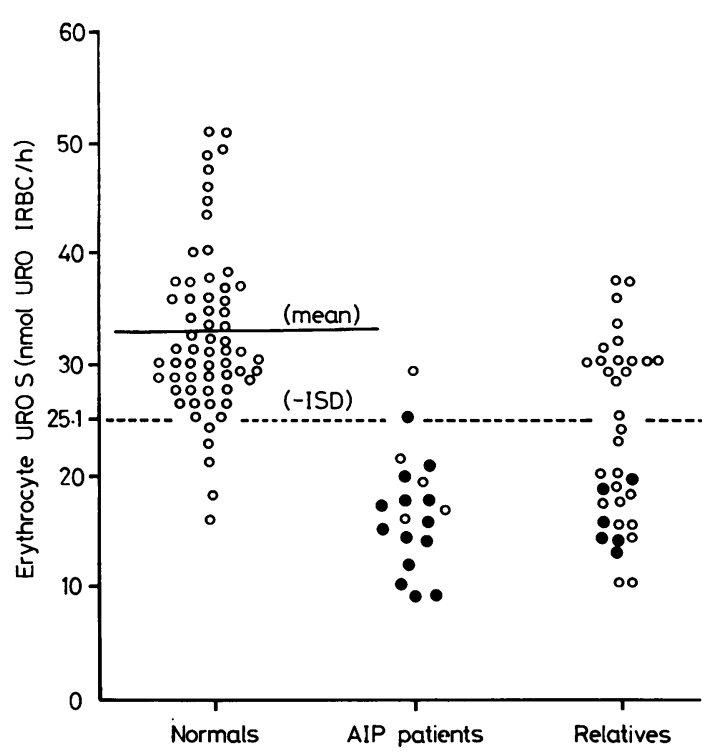

FIG 3 Activity of erythrocyte URO synthase in patients with AIP and in first degree blood relatives in comparison with normal subjects.

significant correlation was found between the activities of leucocyte ALA synthase and erythrocyte URO synthase in the porphyria patients.

The urinary excretion of ALA and PBG was increased in all nine patients studied in clinical attack, but in only five of the ten patients in clinical remission. The activities of leucocyte ALA synthase and erythrocyte URO synthase in the patients in clinical attack were similar to those in the patients in remission (table 1). Similarly, the activities of both enzymes in the patients with increased urinary ALA and PBG were similar to those in the patients with normal urine analysis (table 1).

There was considerable overlap between the normal subjects and the AIP patients with respect to either enzyme (figs 2,3 ). The best separation of normal subjects and patients with AIP with respect to leucocyte ALA synthase was obtained by using the mean value of the normal subjects plus $1 \mathrm{SD}$, that is, $250 \mathrm{nmol} \mathrm{ALA} / \mathrm{g}$ protein/h. All 19 patients had a value of more than this and all but 12 of the $63(19 \%)$ normal subjects had a value less than this (table 2). The most useful separation with respect to erythrocyte URO synthase was found to be equal to the mean value of the normal subjects minus $1 \mathrm{SD}$, that is, $25 \cdot 1 \mathrm{nmol} \mathrm{URO} / \mathrm{RBC} / \mathrm{h}$. All but one of the 19 AIP patients had a value of less than this and all but seven ( $11 \%$ ) of the normal subjects had a value of more than this. Much improved separation of normals and AIP patients was obtained by using
TABLE 1 Activities of leucocyte ALA synthase and erythrocyte URO synthase in relation to excretion of porphyrin precursors and clinical status in patients with $A I P$

\begin{tabular}{|c|c|c|c|c|}
\hline & \multicolumn{2}{|c|}{$\begin{array}{l}\text { Urinary } A L A \text { and } \\
P B G\end{array}$} & \multicolumn{2}{|c|}{ Clinical status } \\
\hline & $\begin{array}{l}\text { Normal } \\
(n=5)\end{array}$ & $\begin{array}{l}\text { Increased } \\
(n=14)\end{array}$ & $\begin{array}{l}\text { Remission } \\
(n=10)\end{array}$ & $\begin{array}{l}\text { Attack } \\
(n=9)\end{array}$ \\
\hline $\begin{array}{l}\text { Mean activity } \\
\text { L ALA synthase } \\
\text { (nmol ALA/g protein/h) }\end{array}$ & 1050 & 917 & 1118 & 945 \\
\hline $\begin{array}{l}\text { Mean activity } \\
\text { E URO synthase } \\
\text { (nmol URO/l RBC/h) }\end{array}$ & 17 & 16 & 18 & 15 \\
\hline
\end{tabular}

TABLE 2 Prevalence of increased leucocyte $A L A$ synthase activity and depressed erythrocyte $U R O$ synthase activity in normal subjects, patients with AIP, and first degree blood relatives of porphyric patients

\begin{tabular}{llll}
\hline & $\begin{array}{l}\text { Normal } \\
\text { subjects (\%) } \\
(n=63)\end{array}$ & $\begin{array}{l}\text { AIP } \\
\text { patients }(\%) \\
(n=19)\end{array}$ & $\begin{array}{l}\text { AIP } \\
\text { relatives (\%) } \\
(n=35)\end{array}$ \\
\hline $\begin{array}{l}\text { L ALA S }>250 \\
(\mathrm{nmol} \text { ALA/g protein/h) }\end{array}$ & 19 & 100 & 66 \\
$\begin{array}{l}\mathrm{E} \text { UROS }<25 \cdot 1 \\
(\mathrm{nmol} \text { URO/1 RBC/h) }\end{array}$ & 11 & 95 & 57 \\
Both & 0 & 95 & 49 \\
\hline
\end{tabular}

both enzymes. None of the normal subjects had both leucocyte ALA synthase activity of more than $250 \mathrm{nmol}$ ALA/g protein/h and erythrocyte URO synthase activity of less than $25.1 \mathrm{nmol} \mathrm{URO} / \mathrm{l}$ $\mathrm{RBC} / \mathrm{h}$, whereas all but one of the AIP subjects had (table 2).

\section{RELATIVES OF AIP PATIENTS}

Increased urinary excretion of ALA or PBG or both was present in only six of the $35(17 \%)$ first degree blood relatives of AIP patients.

The activities of leucocyte ALA synthase ranged from 96 to $1301 \mathrm{nmol}$ ALA/g protein/h, overlapping both the normal subjects and AIP patients (fig 2). The activities of erythrocyte URO synthase ranged from 10 to $37 \mathrm{nmol} \mathrm{URO} / 1 \mathrm{RBC} / \mathrm{h}$ with a bimodal distribution, one peak corresponding to the mean for the normal subjects and the other to the mean for the AIP patient (fig 3). Of the 35 relatives, 23 $(66 \%)$ had leucocyte ALA synthase activities of more than $25 \mathrm{nmol}$ ALA/g protein/h, $20(57 \%)$ had erythrocyte URO synthase activities of less than $25.1 \mathrm{nmol}$ URO/l RBC/h, and $17(49 \%)$ had both increased leucocyte ALA synthase and depressed erythrocyte URO synthase (table 2). Each of the six relatives with increased urinary excretion of ALA or PBG or both had leucocyte ALA synthase activity of more than $250 \mathrm{nmol} \mathrm{ALA} / \mathrm{g}$ protein/h 
TABLE 3 Biochemical comparison of latent cases of AIP with patients in clinical remission. Leucocyte ALA synthase activity is significantly higher in the latter $(p<0 \cdot 05, t$ test $)$.

\begin{tabular}{llrr}
\hline & & $\begin{array}{l}\text { AIP } \\
\text { patients in } \\
\text { remission } \\
(n=10)\end{array}$ & $\begin{array}{l}\text { Latent AIP } \\
\text { subjects } \\
(n=17)\end{array}$ \\
\hline L ALAS & Mean & 988 & 494 \\
(nmol ALA/g protein/h) & Range & $273-3011$ & $317-1301$ \\
E UROS & Mean & 18 & 16 \\
$\begin{array}{c}\text { (nmol URO/1 RBC/h) } \\
\text { Percentage with increased } \\
\text { urinary ALA and PBG }\end{array}$ & Range & $9-29$ & $10-25$ \\
\hline
\end{tabular}

and erythrocyte URO synthase activity of less than $25 \cdot 1 \mathrm{nmol}$ URO/1 RBC/h.

When relatives were separated into normals and latent AIP, the sex distribution remained very similar to that for the total group (57\% females), irrespective of whether the separation was determined by increased leucocyte ALA synthase (59\% females), reduced erythrocyte URO synthase $(55 \%$ females), both enzymes (56\% females), or urine analysis (50\% females).

The 17 relatives with increased activity of leucocyte ALA synthase and depressed erythrocyte URO synthase activity (that is, latent cases of AIP) were compared biochemically with the ten AIP patients in clinical remission. Erythrocyte URO synthase activity was similar in the two groups, but leucocyte ALA synthase activity was significantly increased in the patients who had experienced a clinical attack, and a higher percentage of the latter group had increased urinary excretion of ALA and PBG (table 3).

\section{Discussion}

The genetic trait for AIP is known to be inherited in an autosomal dominant manner. All the relatives examined were first degree blood relatives of cases of AIP and therefore approximately $50 \%$ can be expected to carry the gene. Only $17 \%$ of the relatives had increased urinary excretion of ALA or PBG or both and this is consistent with previous studies, confirming that urine analysis detects only one in every three latent cases.

The measurement of erythrocyte URO synthase activity allows the detection of more latent cases, but considerable overlap occurs between normal and porphyric subjects. The use of leucocyte ALA synthase alone also suffers from the same disadvantage. The present study demonstrates that the use of both enzymes permits much improved separation of normal and porphyric subjects, none of the former and $95 \%$ of the latter having both increased leucocyte ALA synthase and depressed erythrocyte URO synthase activites. Using both enzymes, $49 \%$ of the relatives were classified as latent cases of AIP and there was no bias towards either sex. These findings are consistent with an autosomal dominant mode of inheritance of AIP.

Our study emphasises that the vast majority of patients with the genetic trait for AIP are clinically latent. None of the 17 relatives found to have the trait had experienced any symptoms. There was no clear cut biochemical difference between these latent cases and AIP patients with a history of previous attack but currently in clinical remission, though leucocyte ALA synthase activity was significantly higher and the prevalence of increased urinary excretion of porphyrin precursors greater in the latter. The higher ALA synthase activity in those who have experienced a clinical attack may reflect higher circulating levels of endogenous porphyrinogenic agents. Typical of these endogenous compounds are certain steroid hormones which are produced in excess in porphyric subjects through a deficiency of the steroid $\Delta 4,5 \alpha$ reductase. $^{18}$ It may be worth comparing the steroid profiles of latent and manifest cases. The development of a clinical attack is, however, largely determined by exposure to exogenous precipitating factors and there is no reason for assuming that clinically latent cases are immune to developing attacks later.

The measurement of leucocyte ALA synthase in addition to erythrocyte URO synthase will allow more precise identification of latent cases of AIP especially in situations where it is impossible to examine the full family pedigree. It should, however, be borne in mind that certain factors other than the porphyric trait can induce leucocyte ALA synthase activity in normal subjects. These include enzyme inducing drugs, ${ }^{19}$ acute alcohol ingestion, ${ }^{20}$ and raised blood lead concentrations. ${ }^{21}$

We wish to thank Mr G Forrest and Mr D Jones for their technical assistance and Mrs C Downes for her secretarial assistance.

\section{References}

1 Goldberg A, McColl KEL. The porphyrias. Medicine 1978;11:551-5.

2 Strand LJ, Felsher BF, Redeker AG, Marver HS. Heme biosynthesis in intermittent acute porphyria: decreased hepatic conversion of porphobilinogen to porphyrins and increased delta-aminolaevulinic acid synthetase activity. Proc Natl Acad Sci USA 1970;67:1315-20.

3 Brodie MJ, Moore MR, Goldberg A. Enzyme abnormalities in the porphyrias. Lancet 1977 ;ii:690-701.

4 McColl KEL, Moore MR. The acute porphyrias-an example of pharmacogenetic disease. Scott Med J 1981; 26:32-40. 
5 Grelier M, Grandchamp B, Phung N, et al. Detection de la porphyrie aigue intermittente par le dosage de l'urosynthetase. Nouv Presse Med 1977;6:1045-7.

6 Whitfield JB, Stewart PM, Hensley WJ. Uroporphyrinogen-1-synthetase activity in the diagnosis of acute intermittent porphyria. Clin Chem 1975;21:981-2.

7 Sassa S, Granick S, Bickers DR, Bradlow HL, Kappas A. A microassay for uroporphyrinogen 1 synthase, one of three abnormal enzyme activities in acute intermittent porphyria, and its application to the study of the genetics of this disease. Proc Natl Acad Sci USA 1974;71:732-6.

8 Doss M, Tiepermann RV. Uroporphyrinogen-synthase in Erythrocyten bei akuter intermittierender porphyrie: Neue pathobiochemische Aspekte. J Clin Chem Clin Biochem 1978;16:111-8.

- With TK, Pedersen JS. Uroporphyrinogen synthetase in erythrocytes. Its diagnostic value in latent acute intermittent porphyria with special regard to the gene penetrance. Dan Med Bull $1981 ; 28: 27-34$.

10 Astrup EG. Family studies on the activity of uroporphyrinogen 1 synthase in diagnosis of acute intermittent porphyria. Clin Sci Mol Med 1978;54:251-6.

11 Lamon JL, Frykholm BC, Tschudy DP. Family evaluations in acute intermittent porphyria using red cell uroporphyrinogen 1 synthase.J Med Genet 1979;16:134-9.

12 Kreimer-Birnbaum M, Bonkowsky HL, Bottomley SS. Experience with the red cell uroporphyrinogen synthase assay in kindreds with acute intermittent porphyria. Int $J$ Biochem 1980;12:807-10.

18 Lowry OH, Rosebrough NJ, Farr AL, Randall RJ. Protein measurement with the Folin phenol reagent. J Biol Chem 1951 ;193:265-75.
14 Moore MR, Thompson GG, Ippen H, Seubert A, Seubert $S$. The biosynthesis of haem in congenital (erythropoietic) porphyria. Int J Biochem 1978;9:933-8.

15 McColl KEL. The acute hepatic porphyrias. MD thesis, Glasgow University, 1981.

16 Frydman RB, Feinstein G. Studies on porphobilinogen deaminase and uroporphyrinogen III cosynthetase from human erythrocytes. Biochim Biophys Acta 1974;350: 358-73.

17 Mauzerall D, Granick S. The occurrence and determination of delta-aminolaevulinic acid and porphobilinogen in urine. J Biol Chem 1956;219:435-46.

18 Bradlow HL, Gilette PN, Gallagher TF, Kappas A. Studies in porphyria. II Evidence for a deficiency of steroid $\Delta 45 \alpha$ reductase in acute intermittent porphyria. $J$ Exp Med 1973;138:754-63.

19 McColl KEL, Moore MR, Thompson GG, Goldberg A. Induction of delta-aminolaevulinic acid synthase in leucocytes of patients on phenytoin therapy-comparison with changes in rat hepatic tissue. Br J Clin Pharmacol 1980;9:327-31.

20 McColl KEL, Moore MR, Thompson GG, Goldberg A. Acute alcohol consumption and haem biosynthesis in peripheral blood cells. Scott Med J 1979;24:255.

21 Campbell BC, Brodie MJ, Thompson GG, Meredith PA, Moore MR, Goldberg A. Alterations in the activity of enzymes of haem biosynthesis in lead poisoning and acute hepatic porphyria. Clin Sci Mol Med 1977;53:335-40.

Requests for reprints to $\operatorname{Dr} K$ E L McColl, Department of Medicine, Gardiner Institute, Western Infirmary, Glasgow G11 6NT. 